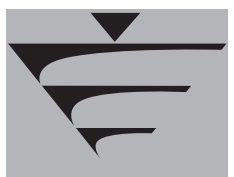

\title{
Erratum: Observations on reservoir risk designation for the amended Reservoirs Act
}

Andrew T. Pepper BSC, CEng, MICE, FCIWEM Principal, ATPEC River Consultancy, Camberley, UK

The publisher regrets that the following error appeared in this paper when it was published in Dams and Reservoirs 24(1): $19-22$.

The first line of the final bullet under the subheading 'Conclusions' read:

'The process will be introducing obligations to 19 undertakers and in such circumstances it would appear to be unreasonable
Christopher W. Scott BSc, MSc, CEng, FICE

Managing Director - MEIA, Black \& Veatch, Redhill, UK

to require significant expenditure to clarify a provisional designation made on a conservative basis.'

It should have read:

'The process will be introducing obligations to undertakers and in such circumstances it would appear to be unreasonable to require significant expenditure to clarify a provisional designation made on a conservative basis.' 